für Balneologie. His principal original works in balneology were "Handbuch der allgemeinen und speciellen Balneotherapie" (third edition, 1875) and "Grundriss der klinischen Balneotherapie" (1897), while his chief gynæcological publications, in order of their appearance, were "Über den Einfluss der Fettleibigkeit auf die weiblichen Sexualorgane"(1873), "Das klimakterische Ältern der Frau" (1874), "Die Sterilität des Weibes" (1895), and "Geschlechtsleben des Weibes in physiologischer, pathologischer und hygienischer Beziehung" (1904), which was translated into English by M. Cedar Paul in 1910 under the title of "The Sexual Life of Woman". An autobiographical work entitled "Erlebtes und Erstrebtes: Erinnerungen" appeared in 1914. He died at Marienbad on August 24, 1918.

\section{Gustave Le Bon}

Dr. Gustave Le Bon, a prominent psychologist, ethnologist and natural philosopher, was born at Nogent Le Notru, Eure-et-Loire, on May 7, 1841. He started his career as a medical officer in the French Army and served in the Franco-Prussian War of 1870-71, but afterwards gave up the practice of medicine and travelled extensively in Europe, Africa and Asia. In 1884 he was ordered by the French Government to report on the Buddhist monuments in India. The results of his investigations were published in "La Civilisation de l'Inde" (1884) and "Les Monuments de l'Inde" (1894). He is best known, however, for his works on psychology, especially "La Psychologie des foules" (1895), which went through twenty-seven editions and was translated into many foreign languages. $\mathrm{He}$ also wrote on psychology in relation to the French Revolution, the War of 1914-18, socialism and education. His chief contributions to natural philosophy consisted in his "Evolution de la matidre" (1905) and "Evolution des forces" (1907). An anatomical and mathematical study on variations in the size of the cranium won him a prize from the Paris Academy and the Anthropological Society of Paris. He was founder and for some years director of the Bibliothèque de philosophie scientifique. $\mathrm{He}$ died on December 14, 1931.

\section{Announcements}

Pror. A. V. HIrL, M.P., one of the secretaries of the Royal Society, has been elected a foreign associate of the U.S. National Academy of Sciences.

Ar a recent meeting of the official and family trustees of the British Museum, Cardinal Hinsley, Archbishop of Westminster, and Sir William Bragg, director of the Royal Institution, were elected to the Trust.

Dr. E. L. Kennaway, of the Royal Cancer Hospital, London, and Dr. J. W. Cook, regius professor of chemistry in the University of Glasgow, have been awarded the annual Katherine Berkan Judd prize of a thousand dollars by the Memorial Hospital for the Treatment of Cancer and Allied Diseases, for outstanding contributions to the knowledge of the cause and cure of cancer during 1939 and 1940.
A Decres depriving Mlle. Eve Curie of French citizenship and confiscating her property was signed by Marshal Pétain in Vichy on May 5.

AT the anniversary meeting of the members of the Royal Institution held on May 1, the following officers were elected : President, Lord Eustace Perey; Treasurer, Sir Robert Robertson; Secretary, Major Charles E. S. Phillips.

A NEW institute of hygiene and medical chemistry has recently been established at Göttingen.

AT the recent meeting of the Indian Science Congress at Benares, the Indian Society of Genetics and Plant Breeding was inaugurated. The following officers were elected for the year 1941: President, Rao Bahadur T. S. Venkatraman; Vice-Presidents, Dr. W. Burns, Mr. K. Ramiah ; Secretary, Dr. B. P. Pal ; Treasurer, Dr. S. Ramanujam; Councillors, Dr. V. K. Badami, Dr. B. S. Kadam, Dr. J. S. Patel, Dr. T. S. Sabnis. The Society will publish a journal in which papers on genetics, plant breeding and cytology will be published.

A MEETING for the inauguration of a Radiography Group of the Institute of Physics will be held at 6.0 p.m. on May 20, in the Lecture Hall of Messrs. Kodak, Ltd., Harrow. All who are interested in the uses of X-rays in industry, whether members of the Institute of Physics or not, are invited to attend.

THE following awards for 1940 of the Institution of Mining and Metallurgy have recently been announced : Consolidated Gold Fields of South Africa Limited Gold Medal to Mr. C. R. Julian for his paper on "Underground Mining at Rio Tinto, Spain"; Consolidated Gold Fields of South Africa Limited Premium of forty guineas conjointly to Mr. J. Spalding and Mr. T. W. Parker for their paper on "Air-Conditioning Plant at the Ooregum Mine-Kolar Gold Field"; William Frecheville Students' Prize of ten guineas conjointly to Mr. J. E. Denyer and Mr. K. C. G. Heath for their paper on "Mining and Milling Tin-Tungsten Ore at Mawchi Mine, Burma". The Council has also elected Mr. H. K. Picard to honorary membership, in recognition of his distinguished services to metallurgy.

Messrs. Charles Baker, of 244 High Holborn, London, W.C.1, are desirous of making an appeal to readers of NATURE to offer for sale certain apparatus which they are able to release for work of national importance. The whole of the British scientific industry is engaged on the production of apparatus for war purposes, the result being that the supply of instruments required for research, education and routine inspection work is severely limited. The demand for such instruments is constant, and increasing from every quarter, not only from official sources, but also from the industries engaged on work of the greatest importance. The following apparatus is of special interest : microscopes, optical equipment and accessories, telescopes, balances, spectrometers, refractometers, surveying apparatus, slide rules and drawing instruments. 